\title{
Work disability in fibromyalgia and other soft tissue disorders: analysis of preventive benefits in Brazil from 2006 to 2015
}

\author{
Ana Paula Monteiro Gomides ${ }^{1 *}$ D, Josierton Cruz Bezerra², Eduardo José do Rosário e Souza ${ }^{3}$, \\ Licia Maria Henrique da Mota ${ }^{1}$ and Leopoldo Luiz Santos-Neto ${ }^{1}$
}

\begin{abstract}
Background: Fibromyalgia is a common chronic disease characterized by persistent diffuse pain, fatigue, sleep disorders and functional symptoms.

The disease can have negative consequences in personal and social life, in addition to significant public health expenses caused by treatment and work leave.

The purpose of this article is to evaluate the number of social security benefits granted due to incapacity for work in Brazil in patients with ICD M79 and variants in the period 2006-2015.

There has been no previous study with data referring to work withdrawals caused by fibromyalgia in Brazil.

Methods: Data for this study were obtained through an official Social Security platform. The disability and retirement benefits were analyzed.

Results: A total of 95,882 social security disability benefits were granted to ICD M79 and variants in the period from 2006 to 2015.

Regarding gender, 69,420 benefits (72.3\%) were granted to women and 26,562 (27.7\%) to men. Regarding the types of benefits, we found 93,556 (97.5\%) temporary withdrawals from work and 2426 (2.5\%) permanent withdrawals. When comparing the initial and final years, we observed a significant reduction in the number of awards: 15,562 in 2006 to 6163 in 2015.

Conclusion: Fibromyalgia was an important cause of withdrawal due to incapacity for work in Brazil, with consequent public health expenditure.

These data may serve as a basis for new studies and can alert professionals of the need for adequate management of fibromyalgia to reduce work withdrawal and its consequences.
\end{abstract}

Keywords: Fibromyalgia, Incapacity for work, Social security benefits

\section{Background}

Fibromyalgia is a chronic disease characterized by persistent diffuse pain, fatigue, sleep disorders and, in most cases, other associated functional symptoms [1]. This disease has a common framework, with an estimated global prevalence of between 5 and $15 \%$ of the general population [2-4]. In recent years, several mechanisms have been studied, but their etiopathogenesis remains unknown $[1,5]$.

\footnotetext{
* Correspondence: anapmgomides@gmail.com

${ }^{1}$ Programa de Pós-Graduação em Ciências Médicas, Faculdade de Medicina, Universidade de Brasília, UnB, CEP, Brasília, DF 70910-900, Brazil Full list of author information is available at the end of the article
}

Patients with fibromyalgia often report worsening of quality of life, changes in social life and reduced productivity at work, especially when there are associated depressive symptoms. These facts can generate negative effects on personal and social life, along with significant public health expenditures caused by treatment and work withdrawals [6-11].

Although the complaints of productivity reduction in patients with fibromyalgia are frequent, there are few studies in the literature that can measure this probable consequence of the disease.

The objective of this article is to evaluate the number of work withdrawals in patients with fibromyalgia and

(c) The Author(s). 2018 Open Access This article is distributed under the terms of the Creative Commons Attribution 4.0 International License (http://creativecommons.org/licenses/by/4.0/), which permits unrestricted use, distribution, and 
Table 1 List of ICD-10 disease codes from group M79 and its variants

\begin{tabular}{ll}
\hline ICD-10 Disease code & Description \\
\hline ICD M79 & $\begin{array}{l}\text { Other and unspecified soft tissue disorders, } \\
\text { not elsewhere classified } \\
\text { ICD M79.0 }\end{array}$ \\
ICD M79.1 & Myalgia \\
ICD M79.6 & Pain in limb, hand, foot, fingers and toes \\
ICD M79.7 & Fibromyalgia \\
ICD M79.8 & Other specified soft tissue disorders \\
ICD M79.9 & Soft tissue disorder, unspecified \\
\hline
\end{tabular}

other soft tissue disorders (ICD M79 and variants) by analyzing the disability benefits granted by Social Security in Brazil over a period of 10 years.

\section{Methods}

A retrospective study was conducted in which the disability benefits (DBs) granted by Social Security in Brazil were analyzed as a function of fibromyalgia and other soft tissue disorders classified as ICD M79 and its ICD-10 variants, which are specified in Table 1.

The assessment consisted of two types of benefits: disease assistance (temporary work withdrawal) and disability retirement (permanent work withdrawal) during the period from 2006 to 2015.

The data for this study were obtained through the E-SIC portal and the official Social Security platform in which spreadsheets and graphs were composed of numerical and descriptive variables $[12,13]$. A qualitative and quantitative analysis of the data was performed.

\section{Results}

A total of 24,815,916 disability benefits were provided by Brazilian Social Security in the period from 2006 to 2015. Among these benefits (provided for all diseases), 95,882 of the benefits $(0.39 \%)$ were attributed to ICD M79 and variants.

When the DBs were analyzed according to the ICD M79 group, 69,420 benefits (72.3\%) were granted to women and $26,562(27.7 \%)$ to men. The age and salary distributions were also calculated and can be seen in Tables 2 and 3. In relation to the types of benefits, we found 93,556 (97.5\%) benefits from temporary work withdrawal (disease benefit) and 2426 (2.5\%) permanent retirements (disability retirement).

The distribution of concessions per year was analyzed, and more benefits were found in the years 2006 to 2008 . The number of benefits per year and the total benefits in the period from 2006 to 2015 can be seen in Table 4 .

\section{Discussion}

Fibromyalgia has the potential to cause functional impairment in patients when compared with the normal population, especially when there is exacerbation of painful symptoms or associated psychiatric conditions [14-17]. Limitations in work capacity caused by pain, fatigue, cognitive alterations, reduction of muscular strength and physical resistance have been described in the literature [18-20].

The evaluation of the number of work withdrawals for a given disease is important for measuring the disease's impact. In this article, we evaluated the number of work withdrawals by analyzing benefits granted by Social Security in Brazil between 2006 and 2015. We did not find similar articles in the literature for comparison.

In our study, we noted the granting of 95,982 benefits for this group of diseases (ICD M79 and variants) in the analyzed period. The occurrence of $72.3 \%$ of the benefits for the female sex can be easily explained by the very incidence of fibromyalgia and other diseases in this group.

In relation to the age group, the age with the greatest number of benefits was 40 to 49 years (30.3\% of the total), with the greatest number of work withdrawals being between 30 and 59 years old: 88,867 (92.6\%). It is important to emphasize that these withdrawals are predominant during the time of full professional capacity. Within this context, some authors have warned about the need for early evaluation and diagnosis and better management of fibromyalgia to minimize the personal consequences and expenses of withdrawals. The maintenance of the functional and working capacity of the individual, besides the improvement in the quality of life, has also been advocated [20].

Regarding the annual distribution of benefits, there were greater numbers in the years 2006, 2007 and 2008. The rest of the period remained similar. When comparing the initial and final years of the analyzed period, we observed a significant reduction in the number of concessions: 15,562 in 2006 to 6163 in 2015. It is believed that during the analyzed years, there was progressively greater knowledge on the part of the physician regarding fibromyalgia and the current recommendation that removal from work in general should be avoided [20]. Increased rigor when granting benefits by Social Security may be another explanation for the decrease in the number of benefits granted.

The amount paid for disability benefits was mostly up to two minimum wages (89\%), which likely represents the income of most of those insured by the National Institute of Social Security / Social Security. No data were provided on the duration of each benefit.

Table 2 Number of disability benefits granted by ICD M79 (and variants) distributed by age group

\begin{tabular}{llllllllll}
\hline Up to 19 years & $20-29$ years & $30-39$ years & $35-39$ years & $40-49$ years & $50-59$ years & $55-59$ years & $60-69$ years & 70 years and over & Total \\
\hline 808 & 15.415 & 24.661 & 12.944 & 29.070 & 22.192 & 8.578 & 3.700 & 136 & 95.982 \\
\hline
\end{tabular}


Table 3 Distribution of disability benefits for M79 (and variants) by salary range in minimum wages (MW) from 2006 to 2015

\begin{tabular}{|c|c|c|c|c|c|c|c|c|}
\hline Distribution year & $<1 \mathrm{MW}$ & $1-2 \mathrm{MW}$ & 2-3 MW & 3-4 MW & 4-5 MW & 5-6 MW & 6-7 MW & Total \\
\hline 2006 & 7.833 & 5.355 & 1.308 & 527 & 397 & 127 & 2 & 15.562 \\
\hline 2007 & 5.815 & 3.758 & 868 & 364 & 317 & 19 & 0 & 11.154 \\
\hline 2008 & 5.319 & 3.009 & 743 & 284 & 246 & 9 & 0 & 9.615 \\
\hline 2009 & 4.814 & 2.410 & 515 & 262 & 163 & 0 & 0 & 8.169 \\
\hline 2010 & 5.449 & 2.500 & 463 & 268 & 120 & 1 & 0 & 8.811 \\
\hline 2011 & 5.337 & 2.721 & 478 & 241 & 126 & 0 & 0 & 8.916 \\
\hline 2012 & 6.015 & 2.455 & 433 & 268 & 45 & 0 & 0 & 9.224 \\
\hline 2013 & 6.061 & 2.446 & 447 & 243 & 31 & 0 & 0 & 9.240 \\
\hline 2014 & 5.934 & 2.511 & 411 & 241 & 20 & 0 & 0 & 9.128 \\
\hline 2015 & 4.032 & 1.668 & 279 & 158 & 20 & 0 & 0 & 6.163 \\
\hline Total & 56.609 & 28.833 & 5.945 & 2.856 & 1.485 & 156 & 2 & 95.982 \\
\hline
\end{tabular}

Although the vast majority of the benefits granted (97.5\%) were due to temporary withdrawals from work (disease assistance), the large number of such benefits represents an important measure of the financial impact of the disease. In addition, we observed 2426 cases of disability retirement, a fact that deserves extreme attention due to the great personal and social repercussions resulting from the early and permanent departure from the labor market.

\section{Conclusions}

In the present study, we analyzed the group of diseases defined in ICD-10 as M79 and its variants, which encompasses several soft tissue disorders. Future research with specific evaluation for fibromyalgia in patients diagnosed by a rheumatologist should be encouraged.

This paper presents some limitations, such as its retrospective character and the lack of data regarding the occupation of individuals and the duration of benefits. However, it is the first article that analyzes the social security benefits granted by ICD M79 in Brazil through an official and

Table 4 Disability benefits granted by social security for ICD M 79 and variants in the period from 2006 to 2015

\begin{tabular}{llll}
\hline Distribution year & Disease assistance & Disability retirement & Total \\
\hline 2006 & 15.158 & 404 & 15.562 \\
2007 & 10.970 & 184 & 11.154 \\
2008 & 9.289 & 326 & 9.615 \\
2009 & 7.924 & 244 & 8.169 \\
2010 & 8.579 & 232 & 8.811 \\
2011 & 8.726 & 190 & 8.916 \\
2012 & 8.991 & 233 & 9.224 \\
2013 & 8.998 & 242 & 9.240 \\
2014 & 8.912 & 216 & 9.128 \\
2015 & 6.008 & 155 & 6.163 \\
Total & 93.555 & 2.426 & 95.982 \\
\hline
\end{tabular}

reliable database. The analysis covered an extended period, which provides us with relevant information on departures from the last decade. These data may serve as a basis for further studies and should alert professionals and specialist societies to the need for adequate management of fibromyalgia to reduce work withdrawal and its consequences.

\section{Availability of data and materials}

The data for this study were obtained through the E-SIC portal and the official Social Security platform.

\section{Author's contribuitions}

APMG performed the data collection, data analysis and writing of the manuscript. JCB performed data collection and data analysis. EJ do R e S, $\mathrm{LMH}$ da $\mathrm{M}$ and LLS-N revision and writing of the manuscript.

\section{Ethics approval and consent to participate}

Not applicable.

The search involved data from the public domain and did not identify the participants.

\section{Consent for publication}

Not applicable.

Competing interests

The authors have no competing interests to this article to disclose.

\section{Publisher's Note}

Springer Nature remains neutral with regard to jurisdictional claims in published maps and institutional affiliations.

\section{Author details}

${ }^{1}$ Programa de Pós-Graduação em Ciências Médicas, Faculdade de Medicina, Universidade de Brasília, UnB, CEP, Brasília, DF 70910-900, Brazil. National Social Security Institute, Brasília, Brazil. ${ }^{3}$ Santa Casa de Misericórdia Hospital of Belo Horizonte, Belo Horizonte, Minas Gerais, Brazil.

Received: 24 March 2018 Accepted: 15 June 2018

Published online: 11 July 2018

\section{References}

1. Bazzichi L, Giacomelli C, Consensi A, Atzeni F, Batticciotto A, Di Franco M, et al. One year in review 2016: fibromyalgia. Clin Exp Rheumatol. 2016;34(2 Suppl 96):S145-9.

2. Walitt B, Nahin RL, Katz RS, Bergman MJ, Wolfe F. The Prevalence and Characteristics of Fibromyalgia in the 2012 National Health Interview Survey. PLoS One. 2015 Sep 17;10(9):e0138024. 
3. Queiroz LP. Worldwide epidemiology of fibromyalgia. Curr Pain Headache Rep. 2013 Aug;17(8):356.

4. Neumann L, Buskila D. Epidemiology of fibromyalgia. Curr Pain Headache Rep. 2003 Oct:7(5):362-8.

5. Jiao J, Vincent A, Cha SS, Luedtke CA, Kim CH, Oh TH. Physical Trauma and Infection as Precipitating Factors in Patients with Fibromyalgia. Am J Phys Med Rehabil. 2015 Dec;94(12):1075-82.

6. Skaer TL. Fibromyalgia: disease synopsis, medication cost effectiveness and economic burden. PharmacoEconomics. 2014 May;32(5):457-66.

7. Tutoglu A, Boyaci A, Koca I, Celen E, Korkmaz N. Quality of life, depression, and sexual dysfunction in spouses of female patients with fibromyalgia. Rheumatol Int. 2014 Aug;34(8):1079-84.

8. Alok R, Das SK, Agarwal GG, Tiwari SC, Salwahan L, Srivastava R. Problemfocused coping and self-efficacy as correlates of quality of life and severity of fibromyalgia in primary fibromyalgia patients. J Clin Rheumatol. 2014; 20(6):314-6.

9. Lavergne MR, Cole DC, Kerr K, Marshall LM. Functional impairment in chronic fatigue syndrome, fibromyalgia, and multiple chemical sensitivity. Can Fam Physician. 2010;56(2):e57-65.

10. Vervoort VM, Vriezekolk JE, Olde Hartman TC, Cats HA, van Helmond T, van der Laan WH, et al. Cost of illness and illness perceptions in patients with fibromyalgia. Clin Exp Rheumatol. 2016;34(2 Suppl 96):S74-82.

11. Robinson RL, Kroenke K, Mease P, Williams DA, Chen Y, D'Souza D, Wohlreich $\mathrm{M}$, et al. Burden of illness and treatment patterns for patients with fibromyalgia. Pain Med. 2012 Oct;13(10):1366-76.

12. Ministério da Previdência Social. Disponível em: http://www.previdencia.gov.br/

13. E-SIC - Sistema Eletrônico do Serviço de Informação ao Cidadão [Internet]. Disponível em: http://www.acessoainformacao.gov.br/sistema/site/index

14. Schaefer C, Mann R, Masters ET, Cappelleri JC, Daniel SR, Zlateva G, McElroy $H J$, Chandran AB, et al. The Comparative Burden of Chronic Widespread Pain and Fibromyalgia in the United States. Pain Pract. 2016;16(5):565-79.

15. Soriano-Maldonado A, Amris $K$, Ortega FB, Segura-Jiménez V, Estévez-López F, Álvarez-Gallardo IC, et al. Association of different levels of depressive symptoms with symptomatology, overall disease severity, and quality of life in women with fibromyalgia. Qual Life Res. 2015 Dec;24(12):2951-7.

16. Bateman L, Sarzi-Puttini P, Burbridge CL, Landen JW, Masters ET, Bhadra Brown P, et al. Burden of illness in fibromyalgia patients with comorbid depression. Clin Exp Rheumatol. 2016;34(2 Suppl 96):S106-13.

17. Ghavidel-Parsa B, Bidari A, Amir Maafi A, Ghalebaghi B. The Iceberg Nature of Fibromyalgia Burden: The Clinical and Economic Aspects. Korean J Pain. 2015 Jul;28(3):169-76.

18. Tesio V, Torta DM, Colonna F, Leombruni P, Ghiggia A, Fusaro E, et al. Are fibromyalgia patients cognitively impaired? Objective and subjective neuropsychological evidence. Arthritis Care Res (Hoboken). 2015 Jan;67(1):143-50.

19. Kravitz HM, Katz RS. Fibrofog and fibromyalgia: a narrative review and implications for clinical practice. Rheumatol Int. 2015 Jul:35(7):1115-25.

20. Henriksson CM, Liedberg GM, Gerdle B. Women with fibromyalgia: work and rehabilitation. Disabil Rehabil. 2005 Jun 17:27(12):685-94.

\section{Ready to submit your research? Choose BMC and benefit from:}

- fast, convenient online submission

- thorough peer review by experienced researchers in your field

- rapid publication on acceptance

- support for research data, including large and complex data types

- gold Open Access which fosters wider collaboration and increased citations

- maximum visibility for your research: over $100 \mathrm{M}$ website views per year

At BMC, research is always in progress.

Learn more biomedcentral.com/submissions 